\title{
Multivariate analysis as a method for evaluating the pathogenicity of novel genetic $M L H 1$ variants in patients with colorectal cancer and microsatellite instability
}

\author{
FRANCESCA DURATURO $^{1}$, RAFFAELLA LICCARDO ${ }^{1}$, ANGELA CAVALLO $^{1}$, \\ MARINA DE ROSA ${ }^{1}$, GIOVANNI BATTISTA ROSSI ${ }^{2}$ and PAOLA IZZO ${ }^{1,3}$ \\ ${ }^{1}$ Department of Molecular Medicine and Medical Biotechnology, University of Naples 'Federico II'; \\ ${ }^{2}$ Endoscopy Unit, Istituto Nazionale per lo Studio e la Cura dei Tumori, 'Fondazione Giovanni Pascale' IRCCS; \\ ${ }^{3}$ CEINGE Biotecnologie Avanzate, University of Naples 'Federico II', I-80131 Naples, Italy
}

Received March 24, 2015; Accepted May 20, 2015

DOI: $10.3892 /$ ijmm.2015.2255

\begin{abstract}
Loss of function of mismatch repair (MMR) genes, mainly $M L H 1$ and $M S H 2$, manifests as high levels of microsatellite instability (MSI) that occurs in $>90 \%$ of carcinomas in patients with Lynch syndrome (LS). The MSI-high status has also been described in sporadic colorectal cancer (CRC) associated with $B R A F$ gene mutation (V600E); this mutation was not present in LS-associated cancers. The present study performed MSI analysis on 39 CRC patients selected according to Bethesda guidelines, and BRAF V600E genotyping was performed in 26 cases classified as MSI-high or MSI-low (15 MSI-H and 11 MSI-L). These 26 patients were then screened for $M L H 1$ and $M S H 2$ germ-line mutations. Germ-line mutations in these genes were detected in 11/15 patients with MSI-H tumors (73\%) and in 1/11 patients with MSI-L tumors (9\%). Overall, 11 germ-line mutations in $12 / 26$ analyzed patients $(46 \%)$ in these genes were identified. Two of these mutations are novel genetic $M L H 1$ variants not previously described in the literature, c.438A $>\mathrm{G}$ and c.1844T $>$ C. A combination of computational approaches, co-segregation analysis and RNA assay suggested that these novel mutations, silent and missense, respectively, were probably pathogenic. The findings of the present study further emphasized the requirement for genetic testing in patients with a risk for hereditary CRC and has broadened the spectrum of known mutations of the $M L H 1$ gene.
\end{abstract}

Correspondence to: Dr Francesca Duraturo, Department of Molecular Medicine and Medical Biotechnology, University of Naples 'Federico II', 5 Via Pansini, I-80131 Naples, Italy

E-mail: duraturo@dbbm.unina.it

Key words: colorectal cancer, microsatellite instability, Lynch syndrome, computational analysis, RNA assay, segregation analysis, MLH1 gene, novel mutations

\section{Introduction}

The majority of colorectal cancer (CRC) cases annually diagnosed occur due to sporadic events; however, up to 6\% are attributed to known monogenic disorders. To date, an etiological association with CRC has been demonstrated for three hereditary syndromes: Familial adenomatous polyposis (FAP) syndrome (1), $M Y H$-associated polyposis (MAP) syndrome (2) and hereditary non-polyposis colorectal cancer (HNPCC) syndrome or Lynch syndrome (LS). LS is the most common inherited CRC type and is associated with mutations in DNA mismatch repair (MMR) genes (3), mainly $M L H 1$ and $M S H 2$ but also MSH6 and PMS2. A germ-line point mutation in $M S H 3$ was found to be associated with the LS phenotype (4). Besides CRC, the spectrum of LS encompasses other primary tumor types (5). The Amsterdam criteria were the first diagnostic guidelines designed to identify families affected by LS (6). As the Amsterdam criteria were rated as being too stringent and not sufficiently sensitive, the Bethesda guidelines were subsequently developed to improve the identification of patients eligible for genetic testing (7).

Loss of MMR gene function manifests as high levels of microsatellite instability (MSI-H) that occurs in $>90 \%$ of all LS carcinomas (7). The MSI-H status has also been described in sporadic CRC associated with $B R A F$ gene mutation, namely the c.1799T >A (p.V600E) mutation. This mutation is not present in LS-associated cancers (8). Therefore, $B R A F$ mutation testing has been proposed as a means to exclude sporadic MSI CRC cases from germ-line $M M R$ gene testing (9).

The present study assessed the microsatellite instability (MSI) status and BRAF V600E mutations in DNA extracted from tumor tissues of patients selected according to revised Bethesda guidelines. Hence, $M L H 1$ and $M S H 2$ genes were screened for germ-line mutations in patients at risk for LS. By using approaches of previous studies, the present study identified LS patients carrying germ-line mutations in these genes, of which two mutations were novel. Using a combination of computational approaches, co-segregation analysis and RNA assay, a likely pathogenicity of these novel $M L H 1$ mutations was identified in the present study. 


\section{Patients and methods}

Patients. The patients were recruited from several hospitals (AOU Federico II and IRCS Pascale of Naples, AOU SUN of Caserta) in Campania (southern Italy). Thirty-nine subjects with CRC were selected according to Bethesda guidelines (7). All patients selected for the present study belonged to families that did not completely fulfill the Amsterdam criteria but in which multiple members were affected by LS-associated cancer. Moreover, colon cancer was diagnosed in almost all patients at $<50$ years of age with preferential localization at the ascending (right) colon. Furthermore, as negative controls, 100 samples from healthy patients were collected from the Clinical Department of Laboratory Medicine of the hospital affiliated to 'Federico II' university (Naples, Italy).

Samples from all subjects were collected after being granted authorization from the local ethics committee 'Comitato etico per le attività Biomediche-Carlo Romano' of the University of Naples 'Federico II' (protocol no. 120/10). Once the authorization was obtained, the study received ethical approval, and participants' informed and written consent was obtained. For each patient, experiments were performed on DNA extracted from peripheral blood lymphocytes and from paraffin-embedded tumor tissues. For the healthy samples, the DNA was extracted only from peripheral blood lymphocytes.

Isolation of genomic DNA. Total genomic DNA was extracted from $4 \mathrm{ml}$ peripheral blood lymphocytes using a BACC2 Nucleon kit (Amersham Pharmacia Biotech, Amersham, UK). For each paraffin block, five $20-\mu \mathrm{m}$ sections were cut and collected in a $1.5-\mathrm{ml}$ microtube. Briefly, $1 \mathrm{ml}$ xylene was added to each tube followed by incubation at room temperature for $20 \mathrm{~min}$ to completely remove the paraffin. The tubes were then centrifuged at 15,000 rpm for $2 \mathrm{~min}$ and the supernatant was discarded. The pellet was re-hydrated with a descendent gradient series of ethanol (500 $\mu \mathrm{l}$ pure ethanol, $500 \mu 190 \%$ ethanol, $500 \mu 180 \%$ ethanol and $10 \%$ ethanol). The tissue pellet was re-suspended in $1 \mathrm{ml}$ distilled water for $30 \mathrm{~min}$ at room temperature. Subsequently, the DNA was extracted using a BACC2 Nucleon kit (Amersham Pharmacia Biotech).

DNA amplification and microsatellite analysis. MSI was tested on paired samples of lymphocyte DNA and in paraffin-embedded tumor tissues of the colon. The MSI status was evaluated with a fluorescent multiplex system comprising five mononucleotide repeats (BAT-25, BAT-26, NR-21, NR-24 and NR-27), three dinucleotide repeats (D2S123, D5S346 and D17S250) and two tetranucleotide repeats using the CC-MSI kit (AB ANALITICA, Padova, Italy) and subsequent capillary electrophoresis analysis using an ABI 3130 Prism (Applied Biosystems, Fisher Thermo Scientific, Waltham, MA, USA). Tumors were classified as 'highly unstable' (MSI-H), if at least $30 \%$ of the markers showed instabilities and 'with low levels of instability' (MSI-L), if at least $10 \%$ of the markers showed instabilities; if no allele difference between DNA extracted from normal and tumorous tissues was observed, tumors were classified as microsatellite stable (MSS) (7).

BRAF V600E mutation analysis. For BRAF V600E genotyping, genomic DNA extracted from paraffin-embedded and blood lymphocytes from patients with MSI-H and MSI-L tumors were amplified using a customized primer pair (forward primer, exon 15, 5'-TGCTTGCTCTGATAGGAAAATG AGA-3' and reverse primer, exon 15, 5'-CTCAGCAGCA TCTCAGGGCC-3'). PCR reactions were performed in a total volume of $50 \mu \mathrm{l}$ containing $5 \mu \mathrm{l}$ of 10X PCR buffer, $200 \mu \mathrm{M}$ of each dNTP, $25 \mathrm{pM}$ of each primer, $1.5 \mathrm{mM}$ of $\mathrm{MgCl}_{2}, 2 \mathrm{U}$ of FastStart Taq DNA polymerase (Roche, Basel, Switzerland) and $100 \mathrm{ng}$ of genomic DNA. PCR conditions were as follows: $95^{\circ} \mathrm{C}$ for 4 min, 35 cycles with $95^{\circ} \mathrm{C}$ for $30 \mathrm{sec}, 60^{\circ} \mathrm{C}$ for $30 \mathrm{sec}$ and $72^{\circ} \mathrm{C}$ for $45 \mathrm{sec}$, followed by a final extension step at $72^{\circ} \mathrm{C}$ for $7 \mathrm{~min}$. PCR prodoucts were sequenced in forward and reverse directions using an ABI 3100 Genetic Analyser (Applied Biosystems Inc., Foster City, CA, USA).

Mutation analysis: Amplification, denaturing high-performance liquid chrmoatography (dHPLC) and sequencing. All $M L H 1$ and $M S H 2$ exons were amplified, including intron-exon boundaries, on DNA extracted from blood lymphocytes of patients with MSI-H or MSI-L tumors, using customized primer sets. Prior to dHPLC analysis, the polymerase chain reaction (PCR) products were separated on a 1-2\% agarose gel to check for unspecific amplicons. A Transgenomic Wave DNA Fragment Analysis system (3500 HT; Transgenomic, Inc., Omaha, NE, USA) was used to perform dHPLC analysis. Abnormal HPLC chromatograms were identified by visual inspection on the basis of the appearance of one or more additional peaks with a lower retention time. For all samples exhibiting abnormal dHPLC profiles, genomic DNA was re-amplified and sequenced in the forward and reverse directions using an ABI 3100 Genetic Analyser (Applied Biosystems).

In silico analysis. Structural analysis of missense point mutations is important to understand the functional activity of the mutated protein. The present study used three complementary algorithms for functional impact prediction of novel missense variants: Sorting Intolerant From Tolerant (SIFT) (http://blocks.fhcrc.org/sift/SIFT.html) (10), Polymorphism Phenotyping (PolyPhen) (http://genetics.bwh.harvard. edu/pph/) (11) and PredictProtein server (http://www.predictprotein.org) (12). Predictions were based on a combination of phylogenetic, structural and sequence annotation information characterizing a substitution with its position in the protein. In addition, the silent novel variant discovered in the present study was analyzed using the Human Splicing Finder (HSF) software (http://www.umd.be/HSF/) (13), a tool designed to predict the effects of mutations on splicing signals or to identify splicing motifs in human sequences. It contains all available matrices for auxiliary sequence prediction and also presents a novel position weight matrix to assess the strength of $5^{\prime}$ and $3^{\prime}$ splice sites and branch points.

Reverse transcription PCR and quantitative (real-time) $P C R$ ( $q P C R)$ of MLHI cDNA. Total RNA was extracted from lymphocytes of the patient carrying the c.438A $>\mathrm{G}$ mutation in the $M L H 1$ gene and from five normal controls using TRIzol reagent (Invitrogen Life Technologies, Carlsbad, CA, USA). cDNA was synthesized using $1 \mu \mathrm{g}$ total RNA, $500 \mathrm{ng}$ random hexamers and $1 \mu \mathrm{l}$ SuperScript III reverse transcriptase (Invitrogen Life Technologies), in the presence of $4 \mu 15 \mathrm{X} \mathrm{RT}$ 
Table I. Primer sequences and sizes of amplification fragments for $M L H 1$ mRNA quantification.

\begin{tabular}{llc} 
Primer name/specificity & \multicolumn{1}{c}{ Primer sequences $\left(5^{\prime} \rightarrow 3^{\prime}\right)$} & $\begin{array}{c}\text { Amplification } \\
\text { fragment size }(\mathrm{bp})\end{array}$ \\
\hline $\begin{array}{l}\mathrm{c} M L H 1 \text { forward primer, exon 3 } \\
\mathrm{c} M L H 1 \text { reverse primer, exon 5I }\end{array}$ & $\begin{array}{l}\text { CCAGTATTTCTACCTATGGCTTTCGACGTG } \\
\mathrm{c} M L H 1 \text { forward primer, exon 4 }\end{array}$ & GGTTTAGGAGGGGCTTTCAG \\
$\mathrm{c} M L H 1$ reverse primer, exon 5II & AACGAAAACAGCTGATGGAA & 198 \\
$\mathrm{c} M L H 1$ forward primer exon 13 & GATCTGGGTCCCTTGATTGC & 103 \\
$\mathrm{c} M L H 1$ reverse primer, exon 14 & GCAGGGACATGAGGTTCTCC & \\
GUS forward primer & GCTTGGTGGTGTTGAGAAGG & 169 \\
GUS reverse primer & GAAAATATGTGGGTTGGAGAGCTCATT & 120 \\
\hline
\end{tabular}

buffer, $1 \mu$ dithiothreitol $(0.1 \mathrm{M})$ and $1 \mathrm{mM}$ deoxynucleotide triphosphates (Invitrogen Life Technologies). The reaction was run on a PCR thermocycler for $50 \mathrm{~min}$ at $42^{\circ} \mathrm{C}$ in a $20-\mu 1$ reaction volume, heated to $70^{\circ} \mathrm{C}$ for $15 \mathrm{~min}$ and subsequently chilled on ice. PCR amplification reactions of the entire $M L H 1$ cDNA were performed using a customized primer pair (1F 5'-ACGTTTCCTTGGCTCTTCTG-3' and 19R 5'-AATC AATCCACTGTGTATAAAGGAA-3'). Amplified fragments were visualized on an $8 \%$ polyacrylamide gel. Each band was excised from the gel and re-suspended in $30 \mu \mathrm{l}$ water overnight. Then, $1 \mu \mathrm{l}$ was re-amplified and subsequently sequenced using the same primer pair. Next, the relative expression of the cDNA of the patient vs. that of the wild-type controls (10 healthy samples) was evaluated by qPCR based on SYBR-Green fluorescence on a CFX96 Real Time System instrument from Bio-Rad Laboratories, Inc. (Hercules, CA, USA). Three pairs of forward and reverse primers for $M L H 1$ cDNA quantification were used which amplified fragments spanning between exons 3-5, 4-5 and 13-14 (Table I). The $\beta$-glucuronidase gene (GUS) was used as housekeeping gene for normalization. The PCR cycling conditions were as follows: $3 \mathrm{~min}$ at $95^{\circ} \mathrm{C}$ followed by 40 cycles at $95^{\circ} \mathrm{C}$ for $15 \mathrm{sec}, 60^{\circ} \mathrm{C}$ for $30 \mathrm{sec}$ and $72^{\circ} \mathrm{C}$ for $20 \mathrm{sec}$ without final elongation. The specificity of qPCR products was evaluated by melting curve analysis and by visualization on $2.5 \%$ agarose gels containing ethidium bromide on a shortwave $\mathrm{UV}$ radiation transilluminator. To evaluate $\mathrm{qPCR}$ efficiencies, a 10-fold serially diluted cDNA was used for each amplicon, and the slope values given by the instrument were used in the following formula: Efficiency $=\left[10(1 / \text { slope }]^{-1}\right.$. All primer sets had efficiencies of $100 \pm 10 \%$. Each experiment was performed in triplicate.

Relative expression was calculated using the comparative $\mathrm{Ct}$ method and normalized against the $\mathrm{Ct}$ of GUS mRNA to acquire and analyze data, as previously described (14). The qPCR assays were performed using the CFX Manager Software (version 2.1; Bio-Rad Laboratories, Inc.) and were compared with the corresponding values from an average of 10 samples of healthy controls to calculate the relative expression.

\section{Results}

MSI analysis and BRAF V600E mutation detection. The present study performed MSI analysis on 39 unrelated index cases with CRC that fulfilled the revised Bethesda guidelines (5). The MSI-H status was identified in 15/39 DNA samples extracted from tumor tissues of patients, while the MSI-L status was identified in 11/39 patients; tumors of 13 patients were free of MSI (MSS). V600E genotyping was performed in 26 patients classified as MSI-H and MSI-L, and no heterozygous or homozygous patients were observed.

Mutation analysis. All MLH1 and MSH2 exons were analyzed in DNA extracted from 26 patients with MSI-H and MSI-L tumors. As shown in Table II, six germ-line mutations were identified in the $M L H 1$ gene and five in the $M S H 2$ gene. Overall, 11 germ-line mutations were identified in these genes in 12/26 patients; two of which were novel mutations that have not previously been reported in the NCBI SNP database, the Human Gene Mutation Database (http://www.hgmd.cf.ac.uk/ ac/index.php), the International Society for Gastrointestinal Hereditary Tumours group (InSight; http://www.insight-group. org/) or the MMR variants database (15). The two novel DNA variants (c.438A $>\mathrm{G}$ and c.1844T $>\mathrm{C}$ in the $M L H 1$ gene) were not detected in the 100 healthy controls. To verify the pathogenicity of these novel variants, in silico analysis was performed with software used in previous studies (10-13). The results are shown in Table III. In silico analysis performed using the HSF software showed that the silent mutation, c.438A $>\mathrm{G}$ of the $M L H 1$ gene, occurs in a region involved in the splicing process. PCR analysis of the entire $M L H 1$ cDNA showed an absence of amplification product corresponding to the wild-type MLH1 cDNA (Fig. 1A). No abnormal aberrant splicing was identified in this patient; however, PCR analysis showed different amplification products between the patient and the healthy controls. Each amplification product visualized on the gel was extracted and sequenced, and the bands revealed the several splicing isoforms of $M L H 1$ mRNA, as described in a previous study (16). A qPCR experiment was then performed in order to quantitatively assess the $M L H 1$ mRNA expression. Three regions of the $M L H 1$ cDNA (fragments spanning between exons 3-5, 4-5 and 13-14) were amplified using the GUS gene as a reference (Fig. 1B and C). In the patient examined, a quantitative alteration of the $M L H 1$ cDNA was found. In particular, transcripts including exons 3-5 and 4-5, where the mutation occurred, were less quantitatively expressed compared to those in the healthy control samples (Fig. 1C). 


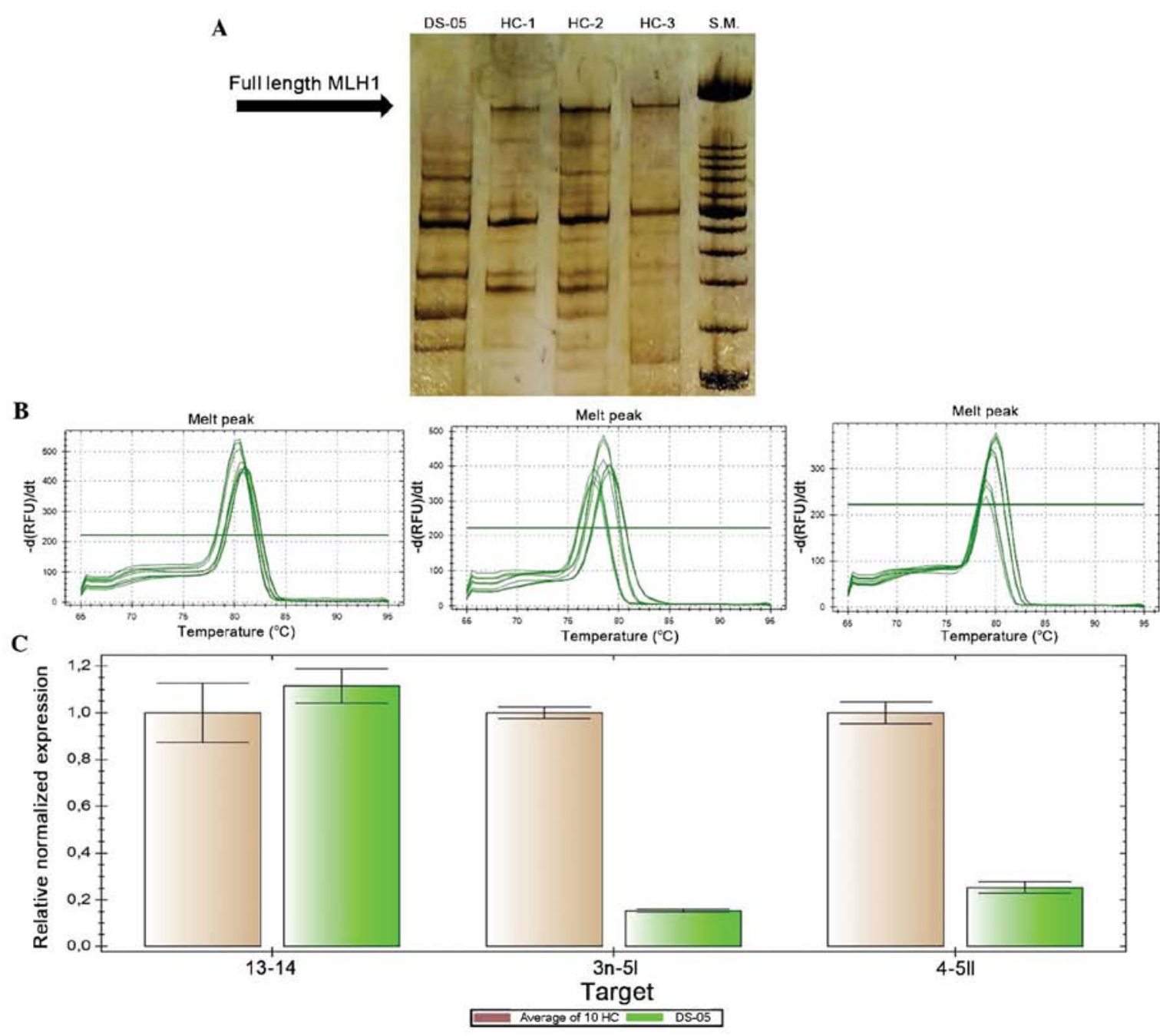

Figure $1 M L H 1$ cDNA analysis of a patient carrying novel silent variant, c.438A $>\mathrm{G}$ and of three healthy controls. (A) Detection of the PCR $M L H 1$ cDNA results on $8 \%$ polyacrylamide gel; no abnormal aberrant splicing is shown; arrow indicates amplification product corresponding to full-length $M L H 1$ cDNA; the other amplification products corresponding to alternative splicing isoforms are visible on the gel. (B) Melting curve analysis of quantitative real-time polymerase chain reaction amplification products corresponding to exons 13-14, 3-5 and 4-5, respectively, of $M L H 1$ cDNA. (C) Relative expression, calculated using the comparative $\mathrm{Ct}$ method, of $M L H 1 \mathrm{cDNA}$, including fragments 13-14, 3n-5, and 4-5II normalized to $\beta$-glucuronidase levels, in an average of $10 \mathrm{HC}$ and in a patient. Values are expressed as the mean \pm standard deviation. S.M., size marker XIV; HC, healthy control; DS-05, patient.

These results indicated that this mutation prevents the formation of the full-length $M L H I$ cDNA but not that of the alternative splicing isoforms that are missing in certain exons.

Computational analysis performed for the novel missense mutation, c. $1844 \mathrm{~T}>\mathrm{C}$ in the $M L H 1$ gene using PolyPhen, SIFT and PredictProtein software (Table III) showed that the consequent change in the amino acid (Leu615Pro) probably had a damaging effect on protein function. Moreover, a clear familial segregation of this mutation was observed for the disease.

The other nine mutations identified in the present study have been previously reported in a mutation database (InSight) (14) as pathogenetic or unclassified variants (UVs) of the $M L H 1$ and $\mathrm{MSH} 2$ genes.

Germ-line mutations in $M L H 1$ and $M S H 2$ genes were detected in 11/15 patients with MSI-H tumors (73\%) and in 1/11 patients with MSI-L tumors (9\%).

In Table II, the identified germ-line mutations, the MSI status of patients' tumors and clinical phenotypes of each subject carrying mutations in $\mathrm{MLH1}$ or $\mathrm{MSH} 2$ genes are listed.

\section{Discussion}

The present study was performed on a cohort of 39 subjects with a diagnosis of CRC at an early age and with a familial background of LS. For all patients that fulfilled the revised Bethesda guidelines, an MSI analysis was performed using DNA extracted from tumorous tissues. Twenty-six of these patients had an MSI-H or MSI-L status, while the remaining 13 patients showed no MSI. Thus, the 26 patients with MSI-H and MSI-L underwent MMR germ-line testing. The 13 remaining subjects with negative LS diagnosis were excluded from these experiments; however, given the selection criteria for enrolment in the present study, these cases are not to be considered sporadic CRC cases, as they were likely to have genetic causes. Recently, it has been described that other Mendelian syndromes with autosomal-dominant inheritance patterns, including the phosphatase and tensin homolog (PTEN) Hamartoma Tumor Syndrome (PHTS), show an overlapping clinical presentation with LS, but tumors do not show any MSI (17). In line with this, in previous studies by our group, one patient with MSS status of 
Table II. Sequence variations evaluated by DHPLC and sequencing analysis in patients with MSI-H and MSI-L.

\begin{tabular}{|c|c|c|c|c|c|c|}
\hline $\begin{array}{l}\text { Patient } \\
\text { ID }\end{array}$ & $\begin{array}{l}\text { Exon } \\
\text { of gene }\end{array}$ & $\begin{array}{l}\text { Nucleotide } \\
\text { change }\end{array}$ & $\begin{array}{l}\text { Amino acid } \\
\text { change }\end{array}$ & $\begin{array}{l}\text { Authors/ } \\
\text { (Refs.) }^{\mathrm{a}}\end{array}$ & $\begin{array}{c}\text { MSI } \\
\text { phenotype }\end{array}$ & $\begin{array}{l}\text { Clinical } \\
\text { phenotype }\end{array}$ \\
\hline $00-13$ & 3 of $h M L H 1$ & c. $304 \mathrm{G}>\mathrm{A}$ & $\begin{array}{l}\text { p.[Glu101Valfs*14, } \\
\text { Glu102Lys] }\end{array}$ & Ellison et al 2001 & MSI-H & $\begin{array}{l}\text { Cancer of small intestine } \\
\text { diagnosed at age } 43 \text {; mother } \\
\text { presented a colon polyp at } \\
\text { age } 73, \text { MUT+. }\end{array}$ \\
\hline DS-05 & 5 of $h M L H 1$ & c. $438 \mathrm{~A}>\mathrm{G}$ & $\mathrm{p}=\mathrm{G} \ln 146$ & Present study ${ }^{\mathrm{b}}$ & MSI-H & $\begin{array}{l}\text { Cancer of the ascending colon } \\
\text { at age } 44 \text { and kidney cancer } \\
\text { at age } 48 \text {; sister died of colon } \\
\text { cancer at age } 53 \text {. }\end{array}$ \\
\hline $01-04$ & 12 of $h M L H 1$ & c. $1321 \mathrm{G}>\mathrm{A}$ & Ala441Thr & Tannergard et al 1995 & MSI-H & $\begin{array}{l}\text { Cancer of the ascending colon } \\
\text { at age } 44 \text {; maternal uncle died } \\
\text { of rectal cancer at age } 57 \text {, } \\
\text { MUT+. }\end{array}$ \\
\hline 08-01 & 16 of $h M L H 1$ & c. $1844 \mathrm{~T}>\mathrm{C}$ & Leu615Pro & Present study & MSI-H & $\begin{array}{l}\text { Rectal cancer diagnosed at } \\
\text { age } 44 \text {; mother with stomach } \\
\text { cancer diagnosed at age } 75, \\
\text { MUT+; daughter and son with } \\
\text { adenocarcinoma and adenoma } \\
\text { with severe dysplasia of the } \\
\text { ascending colon diagnosed } \\
\text { at age } 32 \text { and } 35 \text {, respectively } \\
\text { (both are MUT+). }\end{array}$ \\
\hline 09-08 & 19 of $h M L H 1$ & $\begin{array}{c}\text { 30_32 delTTC, } \\
\text { (3'UTR) }\end{array}$ & & Viel et al 1997 & MSI-H & $\begin{array}{l}\text { Cancer of the ascending colon } \\
\text { at age } 45 \text {; father with kidney } \\
\text { cancer diagnosed at age } 60 \text {, } \\
\text { MUT+. }\end{array}$ \\
\hline $14-35$ & 14 of $h M S H 2$ & c. $2251 \mathrm{G}>\mathrm{C}$ & p.Gly751Arg & De Lellis et al 2013 & MSI-H & $\begin{array}{l}\text { Cancer of the ascending colon } \\
\text { diagnosed at age } 36 \text {; no fam- } \\
\text { ily history (adopted subject). }\end{array}$ \\
\hline $10-04$ & 3 of $h M S H 2$ & c. $435 \mathrm{~T}>\mathrm{G}$ & p.Ile145Met & Kariola et al 2003 & MSI-H & $\begin{array}{l}\text { Cancer of the ascending colon } \\
\text { at age } 35 \text {; maternal } \\
\text { grandmother died of rectal } \\
\text { cancer at age } 77 .\end{array}$ \\
\hline $03-13$ & 5 of $h M S H 2$ & c. $942+3 \mathrm{~A}>\mathrm{T}$ & $\begin{array}{c}\text { p.Val265_Gln31 } \\
\text { 4del }\end{array}$ & Wijnen et al 1997 & MSI-H & $\begin{array}{l}\text { First subject: cancer of the } \\
\text { ascending colon diagnosed at } \\
\text { age } 23 \text {; no reported family } \\
\text { history. Second subject: rectal } \\
\text { cancer and polyp on the } \\
\text { ascending colon diagnosed at } \\
\text { age } 29 \text {; maternal uncle } \\
\text { stomach cancer. }\end{array}$ \\
\hline $11-25$ & 6 of $h M S H 2$ & c. $984 \mathrm{C}>\mathrm{T}$ & $\mathrm{p}=$ Ala328 & Curia et al 1999 & MSI-L & $\begin{array}{l}\text { Tubular-adenoma with severe } \\
\text { dysplasia of the ascending } \\
\text { colon diagnosed at age } 58 \\
\text { and prostate cancer diagnosed } \\
\text { at age } 68 \text {; sister with } \\
\text { adenocarcinoma of the } \\
\text { ascending colon diagnosed at } \\
\text { age } 49 \text {; daughter with } \\
\text { endometrial cancer diagnosed } \\
\text { at age } 35 \text {. }\end{array}$ \\
\hline
\end{tabular}

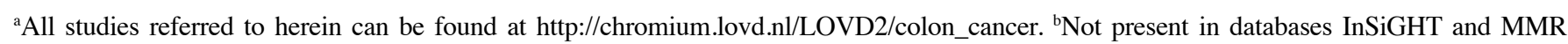
gene variants (15). Nomenclature in accordance with Human Genome Variation Society (www.hgvs.org/mutnomen). MUT+, mutation-positive; MUT-, mutation-negative; MSI-H/L, high/low microsatellite instability; MMR, mismatch repair; DHPLC, denaturing high-performance liquid chromatography; UTR, untranslated region. 
Table III. In silico analysis of the exonic variants in the $M L H 1$ gene.

\begin{tabular}{|c|c|c|c|c|}
\hline Mutation & PolyPhen prediction & SIFT prediction & PredictProtein prediction & HSF prediction \\
\hline c. $438 \mathrm{~A}>\mathrm{G}$ & ND & ND & ND & 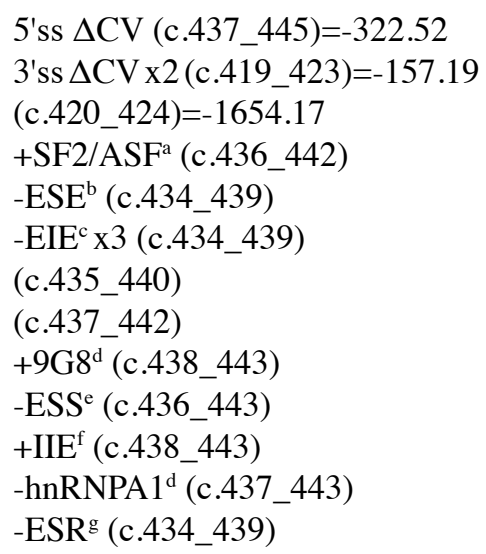 \\
\hline c. $1844 \mathrm{~T}>\mathrm{C}$ & Probably damaged & Damaging & $\begin{array}{c}\text { Strong signal } \\
\text { for mutation effect }\end{array}$ & ND \\
\hline
\end{tabular}

Algorithms and matrices in HSF used to identify the motifs were: ${ }^{\mathrm{a}} \mathrm{ESE}$ finder matrices; ${ }^{\mathrm{b}} \mathrm{RESCUE}-\mathrm{ESE}$ hexamers; ${ }^{\mathrm{C}} \mathrm{EIEs}$ from Zhang et al; ${ }^{\mathrm{d}} \mathrm{GG} 8$ and hnRNP A1 motifs from HSF; ${ }^{\mathrm{e}}$ silencer motifs from Sironi et al; ${ }^{\mathrm{f} I I E s}$ from Zhang et al; ${ }^{\mathrm{g}} \mathrm{ESR}$ from Goren et al. + , a new site created by the mutation; -, the motif was abolished by the mutation. PolyPhen, Polymorphism Phenotyping; SIFT, Sorting Intolerant From Tolerant; ND, not detected; $\mathrm{CV}$, consensus value; $\Delta \mathrm{CV}$, difference between wild-type sites and mutant sites; HSF, Human Splicing Finder.

tumorous tissue, who underwent germ-line testing for the PTEN gene, showed a germ-line mutation in this gene (18), which was associated with the disease in the family (19). Alternatively to the PHTS syndrome, an alteration of inflammatory pathways associated with a dysregulation of cell proliferation pathways (such as WNT/ $\beta$-catenin) in colon mucosa and which may also be inherited in a Mendelian manner $(20,21)$, may have been the underlying cause in the MSS-status CRC cases in the present study. Therefore, for CRC cases without MSI but with a family history of LS, other genetic factors should be considered for making an accurate differential diagnosis of LS.

In the present study, V600E genotyping was performed on DNA extracted from tumorous tissues with MSI-H or MSI-L status (26/39); as expected, in none of these, the mutation of the $B R A F$ gene was detected. An MMR gene mutation was identified in $12 / 26$ selected cases, namely in $11 / 15$ patients with MSI-H tumors and in 1/11 patients with MSI-L tumors; therefore, the mutation detection rate was $46 \%$. The mutation detection rate was significantly higher (73\%) if only MSI-H cases were considered. Although no point mutations were detected in the main MMR genes (MLH1/MSH2), in the remaining 14 patients with MSI-H or MSI-L tumors, the causes of the disease were likely to be other types of mutation, including re-arrangements, deletions or duplications in these same genes (22) or mutations in other MMR genes (PMS2, MSH6 and MLH3) (23,24), which were not detectable in the present study.

The present study identified 11 germ-line mutations in 12 patients; whenever possible, the familial segregation of the mutation with the disease was confirmed (Table II). Two of these germ-line variants were novel mutations in the $M L H 1$ gene that were not found in the control population panel of 100 healthy blood donors. Computational analysis was used to evaluate the putative functional effects of these two novel sequence variants.
PolyPhen, SIFT and PredictProtein software were used for the missense variant and HSF software for the silent variant identified in the $M L H 1$ gene. This software is commonly used to study unclassified variants (UVs) found in patients with LS (25).

The novel mutation c.438A $>\mathrm{G}$ in exon 5 of the $M L H 1$ gene was identified in a patient who had developed two primitive malignancies and showed an MSI-H status. This was a silent variant for which the HSF analysis showed a possible negative effect on the splicing process. In human disease genes, there are several mutations in exonic splicing enhancer control sequences that have been shown to cause aberrant exon skipping $(2,26)$. However, no abnormal aberrant splicing of MLH1 mRNA was found in this patient (no. DS-05), but PCR analysis of the entire $M L H 1$ cDNA showed an absence of amplification product corresponding to wild-type cDNA compared to healthy controls. Furthermore, qPCR analysis detected a significant reduction in $M L H 1$ mRNA expression in tissue from patient no. DS-05, who carried the novel mutations, or rather in transcript fragments that included the exon 5. Although the mechanism of splicing site selection may also significantly differ depending on individual or tissue-specific differences (27), the silent mutation may have altered the normal splicing process, preventing the formation of full-length MLHI cDNA. This may explain why the PCR analysis of the entire $M L H 1$ cDNA showed an apparent increase of the alternative splicing isoforms compared to those in the wild-type cDNA. Therefore, the sole formation of alternative splicing isoforms of the $M L H 1$ gene may have prevented the synthesis of a functional protein and, consequently, determine the mutator phenotype (MSI-H). In the present study, it was not possible to assess the segregation of this variant with the disease in the family of the DS-05 patient. However, in light of the results of the present study and as this silent mutation was 
not identified in the 100 healthy control subjects, it is indicated that this variant is likely to be pathogenetic.

In the present study, the missense mutation c.1844T $>C$ in exon 16 of the $M L H 1$ gene was identified in a patient with rectal cancer. This mutation was identified also in the mother of this proband, who developed stomach cancer at age 75 . The mutation c.1844T $>\mathrm{C}$ was in the highly conserved region of the $M L H 1$ protein and caused an amino acid change from leucine to proline. In silico analysis by PolyPhen, SIFT and PredictProtein software showed that this mutation caused severe damage to the protein functionality. For this mutation, familial segregation with the disease was also observed. Therefore, this mutation was considered as pathogenetic.

The relatives of the two patients with the novel gene mutations (DS-05 and 08-01) are recommended to undergo pre-symptomatic genetic testing.

Finally, it is of note that in the present study, all germ-line mutations identified in the $\mathrm{MLH} 1$ and $\mathrm{MSH} 2$ genes were missense or splicing mutations, and no truncating mutation was identified. Due to their nature, these mutations may lead to variations in the phenotypic expression of the disease alleles; indeed, the patients of the present study had a familial background of atypical LS.

In conclusion, the findings of the present study broadened the spectrum of known mutations of the MLHI gene and reaffirmed that the combination of MSI testing and V600E genotyping for the $B R A F$ gene associated with clinical features, including familial clustering of LS-associated tumors and early age of onset, are relevant predictors to identify LS patients.

Identifying pathogenic mutations in these families will greatly facilitate pre-symptomatic diagnosis and genetic counseling, making better therapeutic decisions for carriers prior to disease manifestation.

\section{Acknowledgements}

The present study was supported by the agreement 2010-2012 between CEINGE and Campania Regional Authority; POR Campania fSe2007-2013.

\section{References}

1. De Rosa M, Dourisboure RJ, Morelli G, Graziano A, Gutiérrez A, Thibodeau S, Halling K, Avila KC, Duraturo F, Podesta EJ, et al: First genotype characterization of Argentinean FAP patients: Identification of 14 novel APC mutations. Hum Mutat 23: 523-524, 2004.

2. De Rosa M, Galatola M, Borriello S, Duraturo F, Masone S and Izzo P: Implication of adenomatous polyposis coli and MUTYH mutations in familial colorectal polyposis. Dis Colon Rectum 52: 268-274, 2009.

3. Lynch PM: The hMSH2 and hMLH1 genes in hereditary nonpolyposis colorectal cancer. Surg Oncol Clin N Am 18: 611-624, 2009.

4. Duraturo F, Liccardo R, Cavallo A, De Rosa M, Grosso M and Izzo P: Association of low-risk MSH3 and MSH2 variant alleles with Lynch syndrome: Probability of synergistic effects. Int J Cancer 129: 1643-1650, 2011.

5. Barrow E, Hill J and Evans DG: Cancer risk in Lynch Syndrome. Fam Cancer 12: 229-240, 2013.

6. Vasen HF, Watson P, Mecklin JP and Lynch HT. New clinical criteria for hereditary nonpolyposis colorectal cancer (HNPCC, Lynch syndrome) proposed by the International Collaborative group on HNPCC. Gastroenterology 116: 1453-1456, 1999.

7. Wolf B, Gruber S, Henglmueller S, Kappel S, Bergmann M, Wrba F and Karner-Hanusch J: Efficiency of the revised Bethesda guidelines (2003) for the detection of mutations in mismatch repair genes in Austrian HNPCC patients. Int J Cancer 118: 1465-1470, 2006.
8. Wang L, Cunningham JM, Winters JL, Guenther JC, French AJ, Boardman LA, Burgart LJ, McDonnell SK, Schaid DJ and Thibodeau SN: BRAF mutations in colon cancer are not likely attributable to defective DNA mismatch repair. Cancer Res 63: 5209-5212, 2003.

9. Domingo E, Laiho P, Ollikainen M, Pinto M, Wang L, French AJ, Westra J, Frebourg T, Espín E, Armengol M, et al: BRAF screening as a low-cost effective strategy for simplifying HNPCC genetic testing. J Med Genet 41: 664-668, 2004.

10. Ng PC and Henikoff S: SIFT: Predicting amino acid changes that affect protein function. Nucleic Acids Res 31: 3812-3814, 2003.

11. Ramensky V, Bork P and Sunyaev S: Human non-synonymous SNPs: Server and survey. Nucleic Acids Res 30: 3894-3900, 2002.

12. Rost B, Yachdav G and Liu J: The PredictProtein server. Nucleic Acids Res 32: W321-W326, 2004.

13. Desmet FO, Hamroun D, Lalande M, Collod-Béroud G, Claustres M and Béroud C: Human Splicing Finder: An online bioinformatics tool to predict splicing signals. Nucleic Acids Res 37: e67, 2009.

14. Costabile V, Duraturo F, Delrio P, Rega D, Pace U, Liccardo R, Rossi GB, Genesio R, Nitsch L, Izzo P, et al: Lithium chloride induces mesenchymal to epithelial reverting transition in primary colon cancer cell cultures. Int J Oncol 46: 1913-1923, 2015.

15. Woods MO, Williams P, Careen A, Edwards L, Bartlett S, McLaughlin JR and Younghusband HB: A new variant database for mismatch repair genes associated with Lynch syndrome. Hum Mutat. 28: 669-673, 2007.

16. Genuardi M, Viel A, Bonora D, Capozzi E, Bellacosa A, Leonardi F, Valle R, Ventura A, Pedroni M, Boiocchi M, et al: Characterization of MLH1 and MSH2 alternative splicing and its relevance to molecular testing of colorectal cancer susceptibility. Hum Genet 102: 15-20, 1998.

17. Mester JL, Moore RA and Eng C: PTEN germline mutations in patients initially tested for other hereditary cancer syndromes: Would use of risk assessment tools reduce genetic testing? Oncologist 18: 1083-1090, 2013.

18. Galatola M, Paparo L, Duraturo F, Turano M, Rossi GB, Izzo P and De Rosa M: Beta catenin and cytokine pathway dysregulation in patients with manifestations of the 'PTEN hamartoma tumor syndrome'. BMC MedGenet 13: 28, 2012.

19. Paparo L, Rossi GB, Delrio P, Rega D, Duraturo F, Liccardo R, Debellis M, Izzo P and De Rosa M: Differential expression of PTEN gene correlates with phenotypic heterogeneity in three cases of patients showing clinical manifestations of PTEN hamartoma tumour syndrome. Hered Cancer Clin Pract 11: 8, 2013.

20. Lynch HT and Lynch J: Lynch syndrome: Genetics, natural history, genetic counseling, and prevention. J Clin Oncol 18 (Suppl): 19S-31S, 2000.

21. Galatola M, Miele E, Strisciuglio C, Paparo L, Rega D, Delrio P, Duraturo F, Martinelli M, Rossi GB, Staiano A, et al: Synergistic effect of interleukin-10-receptor variants in a case of early-onset ulcerative colitis. World J Gastroenterol 19: 8659-8670, 2013.

22. Duraturo F, Cavallo A, Liccardo R, Cudia B, De Rosa M, Diana G and Izzo P: Contribution of large genomic rearrangements in Italian Lynch syndrome patients: characterization of a novel alu-mediated deletion. Biomed Res Int 2013: 219897, 2013.

23. Rahner N, Friedrichs N, Wehner M, Steinke V, Aretz S, Friedl W, Buettner R, Mangold E, Propping P and Walldorf C: Nine novel pathogenic germline mutations in MLH1, MSH2, MSH6 and PMS2 in families with Lynch syndrome. Acta Oncol 46: 763-769, 2007.

24. Lipkin SM, Wang V, Stoler DL, Anderson GR, Kirsch I, Hadley D, Lynch HT and Collins FS: Germline and somatic mutation analyses in the DNA mismatch repair gene MLH3: evidence for somatic mutation in colorectal cancers. Hum Mutat 17: 389-396, 2001.

25. Doss CG and Sethumadhavan R: Investigation on the role of nsSNPs in HNPCC genes - a bioinformatics approach. J Biomed Sci 16: 42, 2009.

26. Cartegni L, Chew SL, Krainer AR: Listening to silence and understanding nonsense: exonic mutations that affect splicing. Nat Rev Genet 3: 285-298, 2002.

27. De Rosa M, Morelli G, Cesaro E, Duraturo F, Turano M, Rossi GB, Delrio P and Izzo P: Alternative splicing and nonsense-mediated mRNA decay in the regulation of a new adenomatous polyposis coli transcript. Gene 395: 8-14, 2007. 